\title{
MIGRATION, WAR, AND THE MAKING OF A TRANSNATIONAL LEBANESE SHII I COMMUNITY IN SENEGAL
}

\author{
Mara A. Leichtman [Assistant Professor] \\ Department of Anthropology, Michigan State University, East Lansing, Mich
}

Mara A. Leichtman: mara.leichtman@ssc.msu.edu

The July 2006 Lebanon war was an important turning point for West African Lebanese. For the first time since their formation as a community, the Lebanese in Senegal organized a demonstration in Dakar displaying solidarity with Lebanon. ${ }^{1}$ This protest illuminates the dynamics between global forces and local responses. Hizbullah's effectiveness in winning the international public opinion of both Sunni and Shi i Muslims in the war against Israel led to a surge in Lebanese diaspora identification, even among communities who had not been similarly affected by previous Lebanese wars. By analyzing the role of a Lebanese shaykh in bringing religious rituals and a Lebanese national identity to the community in Senegal, this article explores how members of the community maintain political ties to Lebanon even when they have never visited the "homeland" and sheds new light on the relationship among religion, migration, and (trans)nationalism.

On 20 July 2006, eight days after the start of the Lebanon war, 3,000 Lebanese demonstrated in the area between Senegal's national television station and Dakar's Grand Mosque. ${ }^{2}$ A token representation of those from outside the Lebanese community joined in the demonstration, including Karim Wade, the president's son; Mustafa Niass, the former prime minister and leader of the opposition; and other Senegalese politicians, professors, religious leaders, and members of nongovernmental organizations. Those in attendance waved Lebanese and Hizbullah flags as well as signs in French, English, and Arabic supporting Lebanon and protesting the Israeli attacks. Lebanese community leaders in Dakar, who had formed the committee Solidarité Liban 2006, gave public speeches denouncing the war and comparing it to the Nazi destruction of the French village Oradoursur-Glane in Normandy on 10 June 1944. They also cited as an example of their "hope and courage" the eventual victory of Nelson Mandela's struggles against apartheid in South Africa. ${ }^{3}$ Such comparisons place the Lebanese struggle alongside other well-known cases of tragedy and human-rights violations while providing examples familiar to a Frencheducated African audience.

The demonstration was followed by a march, led by Shaykh 'Abdul Mun'am al-Zayn. Senegal's Lebanese Shi'i leader was born in 1945 in the south of Lebanon and was trained

\footnotetext{
(C) Cambridge University Press, 2010

Author's note: Fieldwork in Senegal was funded by the J. William Fulbright Program, Population Council, the National Science Foundation, and Michigan State University. All translations are by the author unless otherwise noted. The writing of this article took place during visiting fellowships at the Zentrum Moderner Orient in Berlin and the International Institute for the Study of Islam in the Modern World in Leiden, made possible through grants from Michigan State University. I am grateful for the opportunity to present this research in its various stages at both institutions. A shorter version of this paper was also given at the November 2007 American Anthropological Association meetings at the invited panel "Addressing (In)Justice at the Margins: Transnational Perspectives on the Destruction, Reconstruction, and Re-Destruction of Lebanon," where Augustus Richard Norton and Lara Deeb served as excellent discussants. Joost Beuving, Mamadou Diouf, Calvin Goldscheider, Frances Hasso, Zakia Salime, Roschanack Shaery-Eisenlohr, and three anonymous IJMES reviewers helpfully critiqued this article. I greatly appreciate the careful editing of this manuscript by the $I J M E S$ editorial office. I am also much obliged to my informants in Lebanon and Senegal.
} 
by Ayatollah Abu al-Qasim al-Khu'i, Ayatollah Muhammad Baqir al-Sadr, and other prominent Shi'i scholars in a hawza (religious seminary) in Najaf, Iraq. He currently serves as wakīl (representative) for Ayatollah 'Ali al-Sistani. Sent to Dakar in 1969 by Musa alSadr, the legendary leader of Lebanon's Shi'a and founder of the political party Amal (Afwaj al-Muqawama al-Lubnaniyya), Shaykh al-Zayn was fundamental in bringing Lebanese Shi'a in Senegal "back to Islam" as well as (spiritually if not physically) back to Lebanon. Clerics, through their Islamic institutions, are particularly important in organizing minority or immigrant communities whose members live in close proximity to one another and who face challenges and discrimination from the dominant society. Shaykhs in the diaspora serve not only as religious models for the community to emulate but also as representatives of the country of origin.

How do religious leaders link their congregations to their country of origin and Islam to nationalism? Protesters marched with Shaykh al-Zayn past the Senegalese presidential palace and the U.S. embassy. They ended at the Lebanese Islamic Institute, where there was a well-attended service that included the Syrian and Iranian ambassadors and other dignitaries. Although it is not unusual for heads of state to attend religious ceremonies, it was a clear political statement for two countries with their own goals in Lebanon to be present at such a public event showing solidarity with the Lebanese people. ${ }^{4}$ I was told that the shaykh spoke more about politics at this occasion than usual and that he was full of praise for sayyid Hasan Nasrallah, whereas previously he had always been careful not to demonstrate any attachments to Lebanese political parties. ${ }^{5}$ What is even more remarkable is that many of the protesters who had been living in West Africa for two, three, or even four generations, and had never before marched in the streets of Dakar for a political agenda, had also never visited Lebanon. Although there were many demonstrations against Israel's actions in 2006, with the largest protests taking place in cities in North America, Europe, and the Middle East, I argue that something different was manifesting among Lebanese in Senegal. Taking a public stance against the war broke with the community's previously cautious public profile as a minority not fully accepted in Senegal and can be analyzed as a culmination of their emerging Lebanese identity.

National identity in the diaspora is not only linked to home country solidarity. During the protest, Lebanese also carried the Senegalese flag and signs saying "Merci Sénégal," thanking Senegal for its hospitality for over a century. They hung a banner with the image of the Lebanese national cedar tree on a car rapide, one of Dakar's primary vehicles for public transportation, characteristically blue and yellow, proclaiming in bold, black letters on the front of the large Renault van "Al-hamdu lilläh" (praise God). The car rapide is a symbol of Senegal, reproduced in children's toys and tourist souvenirs. Times of tension in Lebanon underscore for the Lebanese community the insecurity of their situation elsewhere, and they use these periods of political instability in their "homeland" to reaffirm commitment to their "host countries" and express gratitude for having been given the opportunity, now long ago, to settle in West Africa. ${ }^{6}$ Stressing loyalty to Senegal as well as to Lebanon was therefore necessary, and speakers exclaimed: "Long live Senegal! Long live Lebanon! Long live Senegalese-Lebanese solidarity!" This article will explore how Lebanese national identity exhibited by those in the diaspora can sometimes be a response to their exclusion from national belonging in their country of residence.

Religious rituals are one way of reinforcing belonging to the homeland while unintentionally representing the host society as not home. ${ }^{7}$ Louër has reasoned that "any inquiry about the transnational practices of [Shi i I Islamic] movements implies an examination of their relation to religious authority." 8 Through focusing on the work of Shaykh al-Zayn in Senegal, this article thus contributes to a newly emerging scholarship on transnational Shi 'i linkages. ${ }^{9}$ While much of this literature focuses on relationships between Iran and the Levant, I will 
concentrate on ties between Lebanese in West Africa and Lebanon. Through presenting a detailed ethnography of the transformation of Lebanese Shi'i identity in Senegal from the French colonial period to the present day, I insist on the importance of the African example in adding another dimension to our understanding of the relationship between religion and nationalism in the Middle East. Area studies scholars often examine events in the region at the exclusion of related processes taking place in the diaspora.

This article highlights the place of the Lebanese diaspora in Senegal within transnational (Shi i) Islam, where I define transnational Islam as being anchored within two or more nation-states. I focus my investigation of Lebanese diaspora Shi' i Islam around the question Peter Mandaville has asked: "What happens to Islam when it travels, migrates or becomes otherwise "transplanted?", 10 I understand traveling Islam not only to be the movement of Muslims across borders but also the global circulation of religious knowledge through books or cassettes and the transmission of new ideas about Islam over the radio, television, or Internet. Furthermore, I am using a broader conception of religion than one focused solely on the sacred, religious rituals, individual piety, or religious authorities and institutions. I concentrate my analysis on interactions of all of these components of religion, suggesting a new way to think about the globalization of religion through a more in-depth understanding of migration and politics.

I first examine different theoretical understandings of nationalism and then provide a brief history of Lebanese immigration to Senegal. In highlighting the importance of Islamic institutions and authority in the diaspora, the remainder of the article evaluates Shaykh alZayn's success in heightening religious and national awareness among the Lebanese community. I explore his efforts to institute formal religious education through a Friday sermon, encourage public expressions of piety, and introduce new religious rituals in commemorations of 'Ashura' and Ramadan. Finally, I describe other ties Lebanese in Senegal have with Lebanon. This enables me to emphasize the links between religious and political transnationalisms and how Lebanese Shi'a have an understanding of the relationship between Shi'i Islam and Lebanese nationalism that is different from that of Shi'a in Lebanon.

\section{(TRANS)NATIONALISM IN THE LEBANESE DIASPORA}

The case of the Lebanese diaspora in Senegal demonstrates that when "Islam" travels to another Islamic context, it is the national, and not strictly the religious, that becomes the focus of migrant identity. Mandaville has argued the contrary (using case studies of the Muslim minority in England), that " 'the religious' rather than 'the national' becomes the focus of political identity." 11 The relationship between religion and nationalism has recently come to the forefront in scholarship on Lebanese Shi' $i$ politics, in which religion is an integral part of national ideology. Shaery-Eisenlohr asserts that it is when Lebanese Shi'a face other Shi'a that their vision of their community becomes most visible. ${ }^{12}$ She demonstrates how transnational relations between Iran and Lebanon have assisted in breaking the hegemony of Christian narratives of Lebanon as a nation and in placing the historically marginalized Shi'a at the center of Lebanese national politics and self-imagining. How does the link between religion and national politics play out for Lebanese Shi'a living in Senegal? In this African Muslim country, and in contrast to Lebanon, Christians (both Senegalese and Lebanese) are a small minority. ${ }^{13}$

Nationalism is a delicate process in Lebanon and becomes even more multifarious in the Lebanese diaspora. Wimmer and Glick Schiller understand the nation to be a people who share common origins and history as indicated by their shared culture, language, and identity. ${ }^{14}$ It is also an "imagined political community" - an ideological construction that 
forges a link between cultural groups and the state (without a necessarily associated feeling of solidarity). ${ }^{15}$ Yet Reinkowski has argued that academic understandings of nationalism have failed to grasp the complexities of ethnic and national identities in Lebanon and the traditionally weak state, which has been monopolized by certain confessional groups. ${ }^{16} \mathrm{He}$ distinguishes between a Lebanese national identity, a general mass sentiment and historical memory, and the diverse and competing ethnonationalisms of the confessional groups, none of which could rally the support of a majority. National identity has come into existence through "the common experience of a state, the simultaneous experience of war and the failure of competing ideologies and nationalisms." ${ }^{17}$ Most Lebanese born in Senegal have only experienced Lebanon's wars and state bureaucracy from afar, and identify with multiple Lebanese, Senegalese, and French histories, cultures, and languages.

Some have suggested the existence of long-distance nationalism, "a set of identity claims and practices that connect people living in various geographical locations to a specific territory that they see as their ancestral home." 18 A complementary process to globalization and transnationalization, long-distance nationalism spans the globe and, "by utilizing modern global communications networks, crosses ethnonational boundaries with unprecedented ease." ${ }^{19}$ Glick Schiller indicates that long-distance nationalists exhibit active politics, where actions may include "voting, demonstrating, lobbying, contributing money, creating works of art, fighting, killing, and dying." ${ }^{20}$ I agree with Humphrey that longdistance nationalism does not apply to the Lebanese diaspora, especially given that the 2006 protest in Dakar was the first demonstration in support of Lebanon by the community in Senegal. 21

The Lebanese example in Senegal also does not follow Guarnizo, Portes, and Haller's definition of political transmigrants as those who must necessarily be involved in homecountry polities on a regular basis. ${ }^{22}$ Analysis of political transnationalism has been limited to migrant political activism in the host country around home country issues, which may include expatriate voting, electoral campaigns, running for political office, or pursuing foreign-policy goals. ${ }^{23}$ As I have argued elsewhere, degrees of political interest in the country of origin are more relevant than direct political involvement for communities no longer composed only of first-generation migrants. ${ }^{24}$ Although Lebanese in Senegal did protest the July 2006 attacks, this can be seen as symbolic solidarity with victims in Lebanon and is not representative of "active politics."

Humphrey defines the Lebanese diaspora as the "reconstitution of 'Lebaneseness' across generations at a very particular time historically," referring to the Lebanese Civil War (1975-90). ${ }^{25}$ I maintain that in the case of the Lebanese community of Senegal, "Lebaneseness" has been increasing since the arrival of Shaykh al-Zayn in 1969 and the Iranian Revolution of 1979 and that it culminated in the protest against the 2006 Lebanon war, which revitalized diasporic identification. Instead of being an indicator of long-distance nationalism as regular engagement in home-country politics, the 20 July 2006 demonstration in Dakar is an example of transnational collective action, that is, "coordinated international campaigns on the part of networks of activists against international actors, other states, or international institutions." 26

The consequences of Lebanon's wars for its diaspora have not been fully explored. ${ }^{27}$ Hizbullah's actions mobilized the Lebanese diaspora and transnational collective action led to Lebanese national identification. This sense of Lebaneseness became articulated through the larger struggles of Hizbullah as representative of the country as a whole. ${ }^{28}$ This was a Lebanese Shi'i national identity, although it was not religious per se. However, unlike the distinct Shi i national stories in Lebanon of Hizbullah, Amal, and sayyid Fadlallah, as carefully outlined by Shaery-Eisenlohr, many Lebanese in Senegal do not identify with the 
specific political ideologies of these parties. ${ }^{29}$ Rather, Lebanese Shi a in Senegal create their own discourse of origins, illustrated through speeches by visiting Lebanese politicians from both Hizbullah and Amal, stories from Lebanese in Dakar who have "gone back," photos, videotapes, and images of Lebanese Shi i destruction and resistance as portrayed through Lebanese satellite television. This amalgamation of Lebanese Shi i identities, ritualized through religious commemorations, is different from the identities to which Shi'a in Lebanon imagine and refer.

Migration processes serve as agents of religious change. Diasporic religions are not preservations of home-country traditions in their unadulterated form, and scholars have accordingly begun to develop more flexible definitions of religion and have delineated various ways of studying transnational religion or transnational Islam. ${ }^{30}$ Yet Allievi finds the notion of a "Muslim diaspora" to be problematic, as it "lacks many of the basic components of a diaspora, including one common origin and a common point of reference." 31 In contrast, Louër contends that despite their transnational pledge, Shi 'i Islamic movements have always targeted a particular nation-state. ${ }^{32}$ My own research has found that whereas Lebanese Shi'a in Senegal envision Lebanon as their religious center, African converts to Shi $i$ Islam in the same country are much more oriented toward Iran. ${ }^{33}$ Transnational Islam, then, is not as unified a global concept as the literature makes it out to be.

Furthermore, scholarship on the Qur'anic notion of umma, the "imagined community" of Muslims at large, has recently been merged with studies of the Muslim diaspora, where faith is understood to supersede nationalism, race, and ethnicity, especially among Muslims in the West. Castells writes: "[F]or a Muslim, the fundamental attachment is not to the watan (homeland), but to the umma, or community of believers, all made equal in their submission to Allah." 34 Roy argues that Islam has become deterritorialized and globalized and is being reshaped by Western languages, cultures, and ways of life, with the loss of influence of Muslim traditional territories and cultures. ${ }^{35}$ Mandaville examines how Muslims are constructing new frameworks for the practice of Islamic politics in response to the conditions of life in Europe and thereby reconceptualizing the umma through revising their ideas about who, what, and where political community can be. ${ }^{36}$ Sayyid defines the umma as "a community of believing women and men unified by faith and transcending national state boundaries." ${ }^{37} \mathrm{He}$ agrees that a pervasive representation of Muslim migrant communities throughout the developed world has contributed to the assertion of Muslim subjectivity and the formation of a Muslim umma. He therefore contends that even though the Muslim umma is not reducible to displaced population groups and includes the Muslim population in Muslim countries, the umma becomes the manifestation of diaspora because it is an attempt to come to terms with the limits and the crisis of the nation-state. In this article, I add a diaspora component to debates about Lebanese nationalism, while suggesting that the ideology of the umma does not hold for a marginalized Muslim minority community in a Muslim majority country, which instead defines itself along reformulated ethnic, religious, and national boundaries.

\section{LEBANESE IMMIGRATION TO WEST AFRICA}

With a population of 3.5 million residing in Lebanon and approximately double that number living outside their country of origin, the Lebanese constitute one of the oldest and most widespread modern diasporas. ${ }^{38}$ West Africa has long been a destination of Lebanese migrants and refugees, but there is surprisingly little known about these communities and the important role they are playing in Lebanon today. ${ }^{39}$ The significance of the 2006 demonstration and the religious work of Shaykh al-Zayn can only be understood when placed in the historical context of the Lebanese community in Senegal. Lebanese became 
embedded in Senegalese society, building political and economic ties, while they were considered a community apart. It was during times of insecurity in Senegal, resulting from French colonial anti-Lebanese campaigns and Senegalese independence, that the Lebanese community sought to (re)invent its identity, initially uniting as a "secular" ethnic group but later, influenced by divisive politics in Lebanon due to the 2006 war, becoming fractured by religious differences.

Lebanese migrants first arrived in West Africa as the result of a colonial fluke. As early as the 1880s, and especially during the 1920s, emigrants left Lebanon due to economic hardship for Marseilles, the transportation hub of the time. They planned to continue on to the United States or South America, where there had been previous Lebanese immigration. According to today's Lebanese of Senegal, their ancestors boarded ships heading for the Americas but never reached their destination. The ships docked at Dakar, and the French colonial power convinced the Lebanese to stay in West Africa to work as intermediaries in the peanut trade between the French in the cities and Senegalese peasants in the rural areas. Other sources state that health requirements for immigration to the United States were strict, and certain Lebanese failed to satisfy these requirements because of trachoma. Another theory is that many emigrants spent most of their money in Marseilles while waiting for transport and did not have enough money to go to the Americas. The best solution to these difficulties was to settle in West Africa, where fares were cheap, health requirements were lax, and French reports were favorable. ${ }^{40}$

The French soon grew concerned over increasing numbers of Arab immigrants to West Africa and began to see the Lebanese in particular as a threat. In the 1930s and 1940s, French administrators responded with anti-Lebanese campaigns. ${ }^{41}$ These included a policy of segregating Lebanese from Africans in order to prevent the spread of pan-Islamism, panArabism, and anticolonial sentiments, restricting the use of Arabic in the colonies and exercising greater control over the importation of publications in Arabic, and prohibiting Lebanese Muslims from praying in Senegalese mosques and attending local Qur'anic schools. $^{42}$

The Lebanese became a powerful business community, yet they remained a vulnerable minority in Senegal. Becoming socially and politically invisible was the key to their economic success. Clandestine patron-client relationships suited the Lebanese, whose economic actions depended on such collaboration, as well as Senegalese politicians, who benefited from Lebanese financial support but preferred not to publicize it. The Lebanese sensed that change was under way well before independence and established good relations with Senegal's nationalist parties, especially the Bloc Démocratique Sén égalais of Leopold Senghor. ${ }^{43}$ When Senegal became independent on 20 June 1960, some of these Lebanese were "rewarded" by receiving Senegalese citizenship, and the community as a whole was assured of continued protection. ${ }^{44}$

Although the transition from colonial to African administration was relatively smooth, it had been easier for the Lebanese to integrate economically in Senegal under French colonialism. After independence, newspaper and magazine articles, such as one entitled "The Lebanese in Africa: Parasites or Agents of Development?" were overwhelmingly negative and portrayed the Lebanese community as an obstacle to the nationalization of the Senegalese economy ${ }^{45}$ Lebanese were required to employ more Africans in their family-run businesses. They were also affected by rural-development policies, as the independent government first nationalized the production of the peanut monocrop and then slowly diversified the economy, encouraging other food crops. ${ }^{46}$ Many Lebanese were forced to leave the groundnut trade and in consequence migrated from the interior of Senegal to Dakar. Meanwhile, Senegalese textile importers circumvented official circuits and undersold 
Lebanese merchants with untaxed goods. By the late 1970s, Dakar's major Lebanese textile importers began to retreat from the trade. ${ }^{47}$ Those with financial capabilities moved their activities into new fields of investment.

During the colonial period, a large number of Lebanese had both Lebanese and French nationalities. Some felt threatened by independence and saw their decision to apply for Senegalese citizenship as necessary to keep their jobs in certain sectors or to address Senegalese suspicion that the Lebanese community continued to identify with and send remittances to their homeland. Opting for Senegalese citizenship reaffirmed Lebanese commitment to the new nation, and by the end of the 1960s the Senegalese government exerted pressure on Lebanese with Senegalese citizenship to revoke their original nationalities. ${ }^{48}$ These Lebanese resent the fact that although they have Senegalese citizenship they continue to be treated as foreigners and scapegoats in Senegal. As an ethnoracial minority in Senegal, and as a prominent community of businessmen, Lebanese continue to encounter hostility from the Senegalese population. They claim that Senegalese discriminate against them, for example, by excluding them from government positions or targeting them for petty theft and hate crimes. Some Lebanese remark that they will never feel at home in Senegal.

Lebanese settlement in Senegal was first patterned by temporary migration, with the intention of returning to Lebanon to retire and reinstate children in the country of origin. Economic opportunities kept many Lebanese in Africa, and later conflict in Lebanon eliminated the possibility of return. Lebanese pride themselves on having contributed to the development of Senegal and refer to themselves as pioneers of the land. They see themselves as Senegalese yet distinct from the Senegalese and as Lebanese but not like those in Lebanon. Lebanese in Senegal are fluent in Wolof or other local languages and enjoy Senegalese cuisine. Their shops range from small grocers to importers of European fabric and clothing, household items, shoes, furniture, and electronics. They own numerous fast-food restaurants and finer French-style bakeries and cafes that include Lebanese specialties. Responding to the changing Senegalese economy and increased competition in retail, second and third generations have begun to move into industry and the professions, dominating the plastic, paper, and cosmetics sectors and even holding a share in the African textile-manufacturing industry. Traditionally, many Lebanese learned their trade through working their way up to leadership positions in family-run businesses. More recently, some of those with economic means have been sending their children to universities in Europe, Lebanon, and North America. Among the Lebanese of Senegal are also doctors, lawyers, dentists, pharmacists, tailors, and mechanics. Those who can afford to visit Lebanon quickly realize that the social status and standard of living they have secured for themselves in Dakar could never be reproduced in Beirut. ${ }^{49}$

Currently, there are between 15,000 and 30,000 Lebanese in Senegal. While Senegal is a majority Sunni Muslim country, 95 percent of the Lebanese community today is Shi' $\mathrm{i}$ Muslim, with a small Christian population and an insignificant Sunni Muslim presence. Muslim and Christian demographics were more evenly balanced in the first generation of Lebanese in Senegal. Although religious differentiation has remained strong in Lebanon, my informants emphasized in the initial stages of my fieldwork (2000-2004) that "there are no problems between Muslims and Christians in Senegal." Over time, Lebanese religious differences began to be accommodated by the religious institutions. The boundaries between "Muslim" and "Christian" melted away as interreligious marriages became more frequent, children of different religions studied together in Christian or Muslim schools, and all Lebanese community members, Muslim and Christian alike, celebrated weddings, funerals, and even religious holidays together in mosques and churches. ${ }^{50}$ The Lebanese of Senegal lived through the Lebanese Civil War from a distance. Most Lebanese Muslims did not 
distinguish between the Sunni and Shi i denominations; only when they visited Lebanon were they confronted with religious differences. More recently, as a result of the July 2006 war, sectarian divisions in Lebanon have begun to infiltrate Senegal's Lebanese community.

Yet the search for Lebaneseness actually began much earlier, following the period of instability for Lebanese in postindependence Senegal. In 1967, Musa al-Sadr visited Senegal to gain support for his Movement of the Deprived (Harakat al-Mahrumin), which aimed to help the poor people of Lebanon. ${ }^{51}$ His visit simultaneously reinforced a nonsectarian Lebanese identity through his openness to Christians and led to a reaffirmation of Lebanese Shi' i sentiments, especially when prominent Shi i businessmen requested the presence of a shaykh from Lebanon to guide them. Musa al-Sadr kept his promise and in 1969 sent Shaykh 'Abdul Mun'am al-Zayn, whose family he had known previously, to Dakar to cater to the spiritual, social, and cultural needs of Lebanese migrants. Shaykh al-Zayn writes in the introduction to his first book in 1973:

The idea to write this book was born after my arrival in Senegal. The religious situation of the Lebanese community was disastrous with regard to a great void in religious culture and jurisprudence. This culminated in a lack of religious learning and spiritual practices, where prayer, the most important, was not at all satisfactory. ${ }^{52}$

The shaykh slowly succeeded in making the community more aware of religious affairs and obligations. In 1978, he inaugurated the Islamic Social Institution. The following year he established Collège al-Zahra, a primary and secondary Islamic school in Dakar. Later, in 1998, he opened the Arabic Language Institute. ${ }^{53}$ Through regular lectures, classes, individual meetings, and books, the shaykh began to educate Lebanese Muslims about their religion.

Although Lebanese community members, regardless of religious differences, needed to come together as a united ethnic group to make requests common to all Lebanese in Senegal, the 1970s were a politically charged period for Shi i Muslims around the world, and Senegal was no exception. The Iranian Revolution was an example of how Islamic reformist opposition forces could overthrow a Western-influenced secular regime and gave renewed impetus to "political Islamic" struggles throughout the Muslim world. Shi'a in Lebanon, inspired by the success in Iran, began to demand equal rights and to form their own political parties. ${ }^{54}$

\section{FRIDAY PRAYER}

Hirschkind has emphasized the growing importance of cassette sermons in Egypt, and Schulz and Soares have focused on broadcast media for the spread of Islam in Mali. ${ }^{55}$ Cassettes and radio are also important in heightening Islamic education in Senegal but not among the Lebanese, who rely instead on face-to-face interactions with their shaykh. Shaykh al-Zayn's knowledge, authority, and charisma are the key factors in his ability to influence some members of the community (particularly the middle aged and a select group of youth) to become better practicing Muslims. An example of a khutba (Friday sermon) on 11 April 2003, during the war in Iraq, illustrates his style. The shaykh begins, after the usual Islamic supplications, as follows:

Oppressive regimes meet their end even if this be at the hands of other oppressors in Baghdad on the same day the martyrdom occurred of the Eminent Imam, the Pure Martyr, Master Muhammad Baqir al-Sadr (may God have mercy upon him). The issue of assassinating our scholars, whether by the current oppressive regime or by another regime in this world, has been an ongoing issue from times of old. ${ }^{56}$ 
Continuing his sermon, Shaykh al-Zayn explains that Muhammad Baqir al-Sadr was a great Shi'i scholar in Najaf and talks about his intellectual accomplishments. He highlights one of the many crimes of Saddam Hussein's administration, that of imprisoning al-Sadr for protesting the regime's tampering with his book Falsafatuna (Our Philosophy) in order to omit its Islamic ideology and turn it into the philosophical basis for the Iraqi Ba th Party. AlSadr was assassinated on orders from Saddam Hussein in 1980 for refusing to issue a fatwa declaring the $\mathrm{Ba}$ th to be a legitimate Islamic party. ${ }^{57}$

The sermon portrays Shaykh al-Zayn's personal relationship with Muhammad Baqir al-Sadr as one of master-disciple and talks of his teacher's grand ideas of building an Islamic university to reform the hawzāt, the religious seminaries of Iraq, and to modernize Islam.

We live today in an era that is both amazing and remarkable; it is a highly advanced era ... We are now wrestling with philosophies, wrestling with highly advanced civilizations and with formidable scientific progress. We cannot present Islam in the simple old form ... Islam is not a religion of ritual worship only, of mosques only, of pilgrimage only or fasting only. Islam is a religion, a way of life, a system that is complete and comprehensive, beginning at the mosque and ending at the manufacturing plant. This is Islam.

The shaykh ends his sermon by tying his message to Lebanon. He recalls the loss of another Shi' i scholar, Muhammad Baqir al-Sadr's paternal cousin Musa al-Sadr, who had first sent Shaykh al-Zayn to Senegal in 1969 and who disappeared in Libya in 1978.

The khutba is one means of linking Islamic history and scriptures to the present. Shaykh alZayn's powerful sermon educates Lebanese in Senegal about their past and the scholarly traditions of Shi i Islam while preaching a moderate and reformist view of Islam, calling for the religion to be applied to the modern day and age. Shaykh al-Zayn also expresses his political views: his stance against the United States and Saddam Hussein as oppressors and his pride that in Musa al-Sadr the Lebanese had a Shi i scholar equal in greatness to those of Najaf. The flexibility of religion as highlighted by the shaykh makes Shi i Islam attractive to Lebanese Muslims in Senegal. Many attend his sermons because they respect him as a man of knowledge, and community members are able to write anonymous questions about religious practice that are given to the shaykh and publicly addressed. One woman even decided to keep her child after listening to him speak against abortion. Turnout at Friday prayer is considerably more sparse when Shaykh al-Zayn is out of town and is replaced by the Lebanese director of the Arabic Language Institute or a Senegalese shaykh.

\section{PUBLIC EXPRESSIONS OF PIETY}

Some Lebanese have attributed an increase in individual expressions of piety in their community to the shaykh's teachings. Drawing on Mahmood, Deeb defines "public piety" as a bringing together of "the notion of piety meant to be seen with that of piety that is inextricably linked to the public good." 58 Piety that is brought from one's personal space to the public visibly establishes an individual's membership in the religious community by serving as a public marker of religiosity. Since Shaykh al-Zayn's arrival in Senegal, men and women have learned to pray, fast during Ramadan, give to charity, and participate in community service, and more women have begun to wear the veil. These changes in Senegal correspond to similar increases in religiosity throughout the Muslim world, often analyzed as reactions to the failure of post-independence promises of Western-style liberal progress and linked to the advantages of Islamic dress for women who increasingly study or work in mixed-sex environments. ${ }^{59}$ 
Although the hijab is required to enter certain institutions in Senegal, such as the Islamic Institute and Collège al-Zahra, many women in Senegal do not wear the veil, and there is little social pressure to do so. The decision to veil is therefore seen by some as one of great moral strength. Shaykh al-Zayn meets individually with Shi i women who have newly veiled to encourage them in their resolve and educate them on other changes in their daily lives that must accompany this modification of dress. Some women begin to veil when they marry or when their husband goes on hajj to Mecca, either at the husband's request or of their own will to begin a new, more pious way of life.

Yet an increase in veiling is not accepted by all in the Lebanese community. A veiled Lebanese woman in Dakar expressed to me her desire to go back to work, but she feared that some Lebanese businessmen would refuse to hire a veiled woman. Even though Senegal is a Muslim country, the veil is sometimes seen as a deterrent to doing business with the nonMuslim world. Many Lebanese businesses prefer not to place a veiled woman in a position, even secretarial, where she will be seen by Europeans who would perceive the veil as "backward" or be offended by a woman refusing to shake their hands.

There are more veiled women in Senegal today than in the past (among both Lebanese and Senegalese Muslims), yet some Lebanese Shi ' $\mathrm{i}$ women feel pressured not to veil. One woman told me she would like to wear the veil one day. I asked why she did not begin now, and she explained that it was because of the devil: if she lived in a society where everyone were veiled, she could more easily follow suit. However, sunning on the beach is such a way of life for her and her friends, especially on Sundays, when most shops are closed, that it deters her from donning the veil. She also mentioned that her mother-in-law would not support her choice and cited a friend of hers who took off the veil after only two days because it was too difficult.

In contrast, Lebanese in Senegal are surprised when they travel to Lebanon to find that they are criticized for not veiling sooner and are shocked by the large number of veiled women in their villages of origin. In addition, those Lebanese women who choose to veil in Senegal do not pin their scarves according to the distinct styles of Hizbullah or Amal. They each have their own individual style, which is not indicative of their political leanings. ${ }^{60}$ In Senegal, veiling among Lebanese Shi'a is as much a question of fashion, lifestyle, and acceptance by society as it is of religious obligation.

\section{RELIGIOUS RITUALS}

Although Lebanese Shi i Muslims in Senegal are of varying opinions regarding the veil, they are more actively participating as a community in religious rituals that have not historically been part of their social life. I will briefly describe two holiday celebrations, focusing on how they enforce linkages to Lebanon. The first ten days of the Islamic month of Muharram, which commemorate the martyrdom of Imam Husayn at the battle of Karbala, represent a critical aspect of collective identity for Shi'a around the world. Dakar's Islamic Institute was founded in 1978 so the Lebanese would have a husayniyya, a meeting place in which to commemorate 'Ashura'; it was only then that community-wide participation began in Senegal. This involves attending majālis or mourning gatherings, at which the history of the martyrdom of Husayn and his family is retold. The Islamic Institute holds afternoon sessions for women, led by a khațība (female preacher) who is brought annually from Lebanon to recount the story of the battle of Karbala, and evening sessions for both men and women, led by a Senegalese shaykh trained in Lebanon with a beautiful voice. ${ }^{61}$ Shaykh al-Zayn gives twice-daily sermons at both gatherings. A larger commemoration of the tenth day of Muharram is hosted at a private home and attended by men, children, and a few dozen women who help prepare the caldrons of harisa, the customary dish of grain and chicken, 
each stir of which with a large wooden stick is thought to bring a blessing. Lebanese in Senegal commemorate 'Ashura' behind closed doors, and there is no public procession as takes place elsewhere in the Shi' $i$ world.

I attended the majālis at the Islamic Institute, where the lecture hall was filled with women and children dressed in black, the color of mourning. The room was decorated with black wall hangings illustrating the battle of Karbala and the martyrdom of Husayn. A banner with the proverb "Every day is 'Ashura', every land is Karbala [kul yawm 'āshūrä wa kul ard karbala $\vec{a}$ " recalled the slogan Ayatollah Khomeini used to mobilize his followers during the Iranian Revolution. ${ }^{62}$ Lebanese link the tragedy that befell Husayn to the persecution of the Shi'a today. Each day, the khatība narrated a different Muharram event in a style of lamentation, graphically yet poetically detailing the suffering and martyrdom of the Imam, his family, his army. Women came with boxes of pastries and bags of doughnuts and biscuits flavored with anise and sesame seeds and passed around boxes of tissues to those who were eating and those who were crying. The audience was moved by the recitals, which at times became quite emotional as the khatība began to wail in sorrow and the women cried, some passionately, dabbing their eyes, red with tears, and convulsing in sobs. Spending Muharram with the visiting khațība exposes Shi'a in Dakar to 'Ashura' practices in Lebanon.

The shaykh also speaks nightly during the month of Ramadan. One Ramadan evening at the Islamic Institute was different from the others, featuring visitors from Lebanon, whose presentation was videotaped by members of the community. After the recitation of a prayer, Shaykh al-Zayn introduced a man from the Sadr Foundation and a shaykh from the Amal party. The former spoke about the history of the foundation, the life of Musa al-Sadr, Israeli occupation of southern Lebanon, and all the good works of charity the foundation carries out, such as providing vocational schools, orphanages, and other philanthropic institutions to less fortunate Lebanese Shi'a. He listed a number of other organizations throughout Lebanon, talking about the importance of donations. He mentioned that Ayatollah al-Sistani had recently decreed that the khums tax could be paid directly to charity organizations, and he encouraged the audience to give money to charities in Lebanon. ${ }^{63} \mathrm{He}$ then showed a twenty-minute film on the Sadr Foundation and its work. The film began showing scenery from the south of Lebanon, where the institute is based, and the women next to me exclaimed nostalgically, "How beautiful is Lebanon!" Lebanese in Senegal often speak longingly of Lebanon's exquisiteness, of the country's abundance of fruit and vegetables that are not available in West Africa, of the wealth of historical landmarks, and of the magnificence of the Mediterranean Sea. Ramadan thus served not only as a time of fasting to reach a closeness to God and to reflect on those less fortunate but also to bring Lebanese in Senegal closer to Lebanon, unintentionally causing them to lament their own misfortunes in the diaspora.

The introduction of a formal commemoration of 'Ashura' and Ramadan in Senegal is an example of Shaykh al-Zayn's attempt to set up what Abner Cohen has referred to as a ritual community, but the shaykh goes beyond the ritual component by establishing a broader community of interaction. The rise of Shi'a nationalism in Lebanon became informally articulated in Senegal "in terms of religious ideologies, symbols, myths, attitudes, loyalties, ceremonial, and power structure."64 Direct contact with Lebanon, through the visiting khațîba, leaders of Lebanon's Shi'i political parties, and the well-respected Sadr Foundation, transformed religious events into national ones. It is ironic that these rituals also helped to constitute Senegal as not home for the Lebanese. Furthermore, unlike the unity that resulted from this process for Cohen's example of Hausa migrants in Yoruba towns, in Dakar such ritualization served to distance Lebanese Christians from their Muslim compatriots, as Lebanese Shi i politics were articulated alongside Islamic rituals. ${ }^{65}$ 


\section{RECENT TIES TO LEBANON}

Some Lebanese Shi'a in Senegal have learned from Shaykh al-Zayn how to be Shi i Muslims. Recent contact with Lebanon, on either Lebanese or Senegalese soil, reinforces the meaning of being Shi'a. Many members of the second and third generations have never been to Lebanon, but my research suggests that one need not frequently return to Lebanon in order to maintain a Lebanese identity.

In addition to becoming practicing Muslims, many Lebanese of Senegal have become more knowledgeable about Middle Eastern politics. Such interests have been spurred by the recent availability of Lebanese satellite television in Senegal, in particular Hizbullah's channel, alManar. The religious channel consists of news programs followed by political propaganda, evoking images of the collaboration of Hizbullah, Hamas, Lebanon, and the Palestinians against Israel and the United States. ${ }^{66}$ Religion for the Lebanese was suddenly and very visually linked to Middle Eastern politics.

Al-Manar brought Lebanon to Senegal, but Lebanese from Senegal were also brought to Lebanon. The shaykh leads an annual hajj to Mecca following Ramadan, which is organized by a Lebanese travel agency and takes pilgrims from Senegal to Mecca by way of Lebanon. The rise in marriages between men in Senegal and women from villages in southern Lebanon (especially after the Lebanese Civil War, when those in the diaspora were able to visit Lebanon) has also increased contact between the two populations. The engagement ceremony of a Lebanese couple from Senegal was celebrated twice: first in the bride's family's village of origin in Lebanon (captured on videotape for the family in Senegal) and a second time in Dakar. When a Lebanese man born in Senegal died in Lebanon, the Shi i ceremony on the seventh day after his death was conducted by Shaykh al-Zayn at the Islamic Institute in Dakar, videotaped by his family in Senegal, and sent to his relatives in Lebanon.

Due to the economic difficulties in Lebanon, more and more young men have recently come to open shops and restaurants in Dakar, with loans from Hizbullah, which they can pay back once they have established themselves. Senegal has also become a destination for Lebanese officials. Hizbullah deputies visit annually and speak at the Islamic Institute about the need for stronger political and economic relations between the Lebanese of Africa and Lebanon. In March 2004, Nabih Berri, Lebanese speaker of parliament and leader of the Amal party, visited Senegal at the invitation of the president of the Senegalese National Assembly. In recognition of Berri's visit, the municipal council of the city of Dakar renamed Tolbiac Street, in a commercial sector of Dakar lined with Lebanese shops, "Rue du Liban." Berri used the occasion of his diplomatic visit to discuss Middle Eastern and Islamic politics with Senegalese President Wade and to further encourage Shi'i identity among Senegal's Lebanese, addressing the community at the Islamic Institute. ${ }^{67}$

The test for how much ties have increased with Lebanon was the July 2006 Lebanon war. As Élizabeth Picard writes in her 2007 co-edited volume on the war (which I found in Dakar's largest Lebanese-run bookstore), Hizbullah is both a national resistance body and a transnational religious organization. ${ }^{68}$ Like Lebanese diasporas all over the world, Lebanese in Senegal were deeply saddened and outraged by the war, and some had family members who were affected or had gone on vacation themselves to Lebanon and were caught in the conflict. Unlike the Lebanese Civil War, which Lebanese in Senegal followed in a detached manner through the reporting of French television, the round-the-clock reporting by alManar and the horrific images of death and destruction it displayed moved the Lebanese in Senegal to action. 
The 20 July march on the streets of Dakar received much press coverage in Senegalese newspapers. As one subtitle declared: "The conflict in the Middle East is exported to Africa." ${ }^{69}$ Shaykh al-Zayn was quoted in another article: "As God has said in the Qur'an, 'the prayer of the oppressed is unstoppable, so we pray.' And this is why we are demanding of all the mosques in Senegal to pray for the liberation of Lebanon, to pray for the martyrs, to devote tomorrow's sermons to this problem." 70 The Lebanese shaykh even addressed the Senegalese president during the march: "President Wade must ask all the other presidents to turn up their noses [bouder] at the UN Security Council and to subsequently close the Israeli embassy in Senegal." 71 The director of the Department of Central and West Africa in the Israeli Ministry of Foreign Affairs responded: "I don't think that this [Lebanese] community should dictate to Senegal its foreign diplomacy." 72

Lebanese efforts to target Dakar's Israeli embassy eventually lost ground, but this event was significant in marking how the Arab-Israeli conflict played out in Senegal for the first time through the leadership of Shaykh al-Zayn. Furthermore, on 3 August 2006, a silent vigil took place at Dakar's Independence Square, where Lebanese and some Senegalese lit hundreds of candles commemorating the victims of the war, who were pictured on placards. Those in attendance signed their names in solidarity. Included was a large poster with the image of a blue Jewish star and a sketch of a mutilated body with the words "Qana: No Comment." Commemorating the second Qana massacre was especially meaningful because many Lebanese in Senegal originated from the south of Lebanon, including the village of Qana. ${ }^{73}$ Youth draped the Senegalese and Hizbullah flags over their backs, while others wore t-shirts of the Lebanese flag with the image of a clenched fist next to the cedar tree commanding, "Résistons!" Some women dressed as they would for 'Ashura'-all in black wearing a headband with the Arabic words "ya Husayn." This symbolism, along with the sign evoking resistance, is important, as the Lebanese in Senegal have joined those in Lebanon in following the ideology of Hizbullah (and Khomeini) in not passively accepting their persecution as Shi' ${ }^{7}{ }^{74}$

When I returned to Senegal the following summer, "Résistons!" placards could still be found in homes and shops in addition to posters of Nasrallah with the Arabic saying, "anta al-nașr" (you are the victory), a play on Nasrallah's name and the word for victory in Arabic. Although an occasional Lebanese individual in Senegal could previously be found with a Hizbullah keychain or a small magnet on their refrigerator, such images of Lebanese Shi i resistance were never so numerous or so prominently displayed in Dakar as during and after the 2006 war.

The war was not the only Lebanese political event commemorated in Senegal. Hizbullah and Amal deputies came to Dakar in May 2007 for the celebration of the liberation of the south of Lebanon (25 May 2000). Although this reception takes place annually at the Lebanese ambassador's residence, this year it was hosted at the more spacious Sporting Club because a larger audience than usual was expected. ${ }^{75}$ There were many speeches as well as a poet who performed readings about Hizbullah and Lebanon. The deputies spoke about the latest tensions in Lebanon resulting from the siege of the Nahr al-Barid Palestinian refugee camp near Tripoli, condemned the attacks on the Lebanese army by the al-Qa ida-affiliated Fatah al-Islam organization, and declared that Lebanon would survive this latest conflict. Although the July march and August vigil of 2006 were the only public Lebanese demonstrations in Dakar, the Islamic Institute and Maronite Mission had held several private religious services over the previous four years commemorating the "martyrs" of Lebanon, including Prime Minister Rafik Hariri, killed on 14 February 2005; Jibran Twayni, a parliamentarian assassinated in December 2005; and Pierre Jumayil, an anti-Syrian cabinet minister and Christian leader killed in November $2006{ }^{76}$ There were also more general commemorations for all Lebanese who had died during the 2006 war and the Nahr al-Barid struggle in June 
2007. ${ }^{77}$ Although the Lebanese religious institutions in Senegal denounced the violence in Lebanon and officially commemorated its martyrs regardless of their religion, the war led to a divide between Shi $i$ Muslims and Christians. The latter were outraged at the destruction of Lebanon yet blamed Hizbullah for provoking Israeli attacks and feared sayyid Hasan Nasrallah's increasing power. ${ }^{78}$ When I conducted my initial fieldwork in Senegal (between 2000 and 2004) I never heard such talk about Lebanese politics. This latest war in Lebanon has further altered the delicate balance between religion and secular ethnicity among members of the Lebanese diaspora in Senegal.

\section{BACK TO ISLAM OR BACK TO LEBANON?}

How successful has Shaykh al-Zayn been in bringing Lebanese Shi'a "back to Islam"? The shaykh takes pride in the fact that Lebanese Muslims in Senegal are learning about their religion, and many have begun to pray, fast, pay religious taxes, wear the veil, and leave drugs and alcohol behind. Yet Lebanese Shi'a in Senegal are a piously imperfect community. Although the shaykh envisions his work to have made a significant difference, not every community member agrees that he has had an impact on the Shi i community as a whole.

Not all Muslims go to the Islamic Institute. Shaykh al-Zayn's greatest following is among businessmen with little formal education; he has less appeal among Senegal's Lebanese professionals with diplomas from Western universities. A woman who is not regularly present at the shaykh's lectures informed me that some attend because they need him to read the prayer for them. A minority of Lebanese who are literate in Arabic prefer to pray at home. Others have no interest in attending the Islamic Institute at all. Some youth note this; in the words of one university student studying in France, while on holiday to visit his family in Dakar, "God is dead!" Many Lebanese of his generation, especially those with a Western education, do not pray, fast during Ramadan, or observe the other Islamic requirements, which they perceive not to be "modern." He informed me that this notion arises when Lebanese youth observe how Senegalese pray in the middle of the street (which in Dakar's commercial areas is polluted with rotting garbage) on a piece of cardboard or a burlap sack, if not on a prayer rug. Such a sight disgusts certain Lebanese, who remark that Senegalese do not understand the laws of Islamic purity, and it turns off these youth from prayer. While some young Lebanese in their twenties and thirties who have recently become more observant of Islam do populate the Islamic Institute alongside the middle aged and the (fewer) elderly, others prefer to maintain their past lifestyles. One man refers to himself as a "modern Muslim," who drinks, goes dancing, and likes women.

Other Lebanese renounce the commemoration of 'Ashura'. A lawyer declared that he was born and raised a Shi i Muslim but that it did not guide his life and he did not need to cry for Husayn 1,400 years after his death. A woman active in grassroots causes felt that the Shi'a were "fanatics" in following 'Ali, and that they exaggerate when they mourn the death of Husayn by beating their chests and crying for ten days. ${ }^{79}$ She told me that when her mother died, she cried but not for ten days.

Illiteracy in Arabic is perceived by the community as another obstacle to religiosity. Most of the first and second generation can speak the Lebanese dialect but cannot read or write standard Arabic. They are literate in French and fluent in Wolof, the languages they use for their everyday transactions and interactions with Senegalese society. Whereas Shaykh alZayn conducts his Friday sermons in standard Arabic, for him a religious necessity, all other lectures are delivered in the Lebanese dialect. The books he writes in Arabic are translated or transliterated into French for the Lebanese in Senegal. One woman told me she believes in God and has faith but does not practice her religion because she does not understand 
Arabic, and prayer is therefore meaningless to her. A man is ashamed of his illiteracy in Arabic and therefore his inability to read the Qur'an, which he refuses to read in French translation, believing the holy book to be impure in any language other than the language of Islam. The Arabic Language Institute has not had great success in increasing Arabic literacy in Senegal among the French-educated Lebanese population. This struggle with Arabic, the language of Islam and of their homeland, is a source of dishonor and humiliation for many in the Lebanese community of Senegal, especially when confronted by those from Lebanon.

As a community, Senegal's Lebanese Shi'a lack the religious knowledge, literacy in Arabic, and commitment to practicing their faith to enable Shaykh al-Zayn's goals of bringing the Lebanese "back" to Islam to be fully realized. Their transformation, however, can be understood in another way. In creating a "ritual community" of Lebanese Muslims in Senegal, and through this ritual component stressing the wider meaning of belonging to a community of Shi'a, Shaykh al-Zayn has succeeded in making them better Lebanese. I return to the question I raised earlier about what happens when religion migrates. The spiritual journey of Lebanese Shi'a in Senegal can be interpreted as a "return migration" to Lebanon. This occasionally involves actual travel to the homeland but more often only an ideological return to their roots as the homeland migrates to Senegal. The shaykh's powerful sermons, visitors from Lebanon, marriages with women from southern Lebanon, and stories told by others who have gone "back" inform Lebanese who have never been to Lebanon about their country, implanting in them the ethno-religious pride of being Lebanese. Furthermore, satellite television has illustrated the shaykh's efforts more forcefully than he ever intended. The Shi'i message of Hizbullah's channel informs Lebanese in Senegal of their history, their rise to power, and their current struggles, exemplified by the 2006 war. ${ }^{80}$ This leads to tensions in Senegal between Lebanese Shi'a and Christians or Sunnis who do not sympathize with Shi i political endeavors. These frictions go beyond the shaykh's attempt to teach Shi i pride through religious accommodation in Senegal.

Exposure to cross-regional Shi i Islamic forces has resulted in the Lebanese of Senegal more strongly identifying as Lebanese Shi a. Some Lebanese in Senegal are tied to Shi'a around the world through affiliation with marājiı (religious authorities), such as Ayatollah al-Sistani in Iraq. ${ }^{81}$ The commemoration of 'Ashura' in Senegal, part of a larger movement of Shi' $i$ revitalization inspired by the Iranian Revolution, reminds them of Shi'i tragedies in Iraq of both the past and present day. Yet Lebanese women in Senegal are connected with Lebanon through the arrival of the khatība, and the 'Ashura' story has most recently been applied to the 2006 war in Lebanon. Despite the empathy with Shi'a around the world, Islamic holidays in Senegal are used to further Lebanese Shi ' i causes, such as giving charity to the Sadr Foundation and celebrating the independence of the south of Lebanon. Transnational Islam for Lebanese in Senegal is thus a Lebanese Shi i Islam. The Senegalese example suggests that when Islam travels to another Islamic context it is sometimes the national over the religious that becomes the focus of migrant identity. Such a finding diverges from the literature on (Sunni) Muslim minority communities in the West. The Senegalese case stresses the importance of research among Shi i minority groups, whose identity politics differ from Sunni Muslims, and south-south migrant communities, who construct their networks and identities from what Tsing has called "out-of-the-way" places. ${ }^{82}$

It is difficult to separate Lebanese religious and political transnationalisms. These boundaries are further blurred by the incorporation of Lebanese religious organizations such as Hizbullah in the Lebanese parliament and their transformation into political bodies that garner financial and ideological support from co-religionists in the diaspora, who are not (yet) permitted an absentee vote in home-country elections. ${ }^{83}$ How does the diaspora transform the institutions of the polity and its conception of membership? This article has described the spread of the Arab-Israeli conflict to Senegal. Although researchers predict 
that transnational ties will weaken among children of migrants (in the West), I have demonstrated that this depends on the global political context and on levels of security and sentiments of where "home" is located for migrants and their descendants in the country of residence. ${ }^{84}$ This is the case for Lebanese in Senegal, who, while demonstrating against the war in Lebanon-showing political support outside of formal government ties and reaffirming their claim to be part of Lebanon-also felt obliged to reinforce their loyalty to Senegal, where the future of their community is uncertain.

Expanding on Mandaville's reasoning, traveling Islam is not only "travel within Islam" but also travel across time and space, spanning a community's past, present, and future and, especially in the case of Shi 'i Islam, is inextricably linked to national identity and to a secular struggle for equality, human rights, and, at times, self-determination, in addition to power politics. ${ }^{85}$ For Lebanese Shi'a in Senegal, being part of a community still matters, but this does not mean a sense of greater belonging to the all-encompassing Muslim umma, understood by some scholars as the Muslim diaspora at large. The ideology of the umma disintegrates in the face of a Muslim minority's discourse of and responses to political marginalization by the Muslim majority host society.

Lebanese Shi'a in Senegal belong instead to a particular community with ethnic, religious, and national (albeit transnational) boundaries. This community, rooted in Dakar's Islamic Institute, is led by Shaykh al-Zayn, who is a representative of Lebanon. Despite Roy's insistence that Islamic religious debates in the diaspora are no longer monopolized by the learned 'ulama' (scholars and teachers), I have demonstrated that Islamic authorities have not lost their influence. ${ }^{86}$ Shaykh al-Zayn facilitates religious and political ties with the homeland. These ties are fluid and are redrawn over time and in response to global events. Hizbullah has become a transnational organization while remaining a symbol of Lebanese national resistance by reaching out to particular communities of Lebanese Shi'a around the world. Transnational loyalties therefore predominate over other diasporic religious identities, bringing Lebanese in Senegal to action over the destruction of Lebanon and in a declaration of allegiance to the motherland.

\section{NOTES}

1. One difficulty in explaining ethnicity and identity is how to label different groups. It is obvious that today's "nations" of Lebanon and Senegal are not composed of homogenous populations. Furthermore, when members of a group compare themselves to another, the "other," they assume an "us"/"them" system of categorization. Therefore, I adopt a macro perspective that regards "the Lebanese of Lebanon" and "the Senegalese" as single units, the "them." I refer to the ethnic community as "the Lebanese of Senegal."

2. I have been conducting research on the Lebanese community of Senegal and transnational Shi i Islam since 2000, and my fieldwork in Senegal has totaled nearly twenty months. I initially spent two months in Dakar in the summer of 2000, conducted extended fieldwork between September 2002 and January 2004, and have returned regularly to Senegal since then. I spent two weeks in Dakar in June 2006, one month before the start of the July 2006 war, and returned for six weeks the following summer. Although I was not present at the protest, the events were well documented on the website of the Lebanese embassy of Dakar, including the full text of speeches and photos. I also conducted research in Lebanon for one month each in the summers of 2000 and 2001 and returned for one week in May 2007.

3. The full text of this speech can be found online at accessed 15 July 2008http:// www.solidariteliban.comThis website also contains a timeline of the war's events, including disturbing images of death and destruction, and documentation from the protest in Dakar.

4. Syria, which has long dominated Lebanon's foreign policy and has supported Hizbullah, maintained troops in Lebanon from 1976 to 2005. For a historical perspective on Lebanon's ties to Syria see Salibi, Kamal. A House of Many Mansions: The History of Lebanon Reconsidered. Berkeley, 
CalifUniversity of California Press 1988 and Hanssen, Jens. Fin de Siècle Beirut: The Making of an Ottoman Provincial Capital. OxfordOxford University Press2005Iran has had a long history of relations with Lebanon and backs Hizbullah. See Chehabi HE. Distant Relations: Iran and Lebanon in the Last 500 Years. LondonI. B. Tauris2006and Shaery-Eisenlohr, Roschanack. Shi ite Lebanon: Transnational Religion and the Making of National Identities. New YorkColumbia University Press 2008

5. The shaykh was thought to have Amal leanings, although he famously helped negotiate the release of French hostages taken by Hizbullah in the 1980s by traveling between Paris, Beirut, and Tehran. See Péan, Pierre. Manipulations Africaines. ParisPlon2001

6. I am using the term "homeland" and "host country" loosely, as many Lebanese were born in Senegal and have never been to Lebanon.

7. See Tabar, Paul. Ashura in Sydney: A Transformation of a Religious Ceremony in the Context of a Migrant Society. Journal of Intercultural Studies. 2002; 23:285-305.

8. Louër, Laurence. Transnational Shia Politics: Religious and Political Networks in the Gulf. New York: Columbia University Press; 2008. p. 2

9. Chehabi. Distant Relations. In: Mervin, Sabrina, editor. Les mondes chiites et l'Iran. Paris: Karthala; 2007. Shaery-Eisenlohr, Roschanack. Postrevolutionary Iran and Shi' i Lebanon: Contested Histories of Shi i $i$ Transnationalism. International Journal of Middle East Studies. 2007; 39:271-89. Shi ite Lebanon. idem. Pinto, Paulo G. Pilgrimage, Commodities, and Religious Objectification: The Making of Transnational Shiism between Iran and Syria. Comparative Studies of South Asia, Africa and the Middle East. 2007; 27:109-25.

10. Mandaville, Peter. Transnational Muslim Politics. Reimagining the Umma. New York: Routledge; 2001. p. 109

11. Ibid.

12. Shaery-Eisenlohr. Shi ite Lebanon.

13. Approximately four percent of Senegal's population is Christian, with around 1,200 Lebanese Christians.

14. Wimmer, Andreas; Schiller, Nina Glick. Methodological Nationalism and Beyond: Nation-State Building, Migration and the Social Sciences. Global Networks. 2002; 2:301-34. 306.

15. Anderson, Benedict. Imagined Communities: Reflections on the Origins and Spread of Nationalism. New York: Verso; 2006. [1983]

16. Reinkowski, Maurus. National Identity in Lebanon since 1990. Orient. 1997; 38:493-515.

17. Ibid., 512.

18. Schiller, Nina Glick. Long-Distance Nationalism. In: Ember, Melvin; Ember, Carol R.; Skoggard, Ian, editors. Encyclopedia of Diasporas: Immigrant and Refugee Cultures Around the World. New York: Springer; 2005. p. 570

19. Skrbis, Zlatko. Long-Distance Nationalism: Diasporas, Homelands and Identities. Aldershot, U.K: Ash-gate; 1999. p. xiii

20. Schiller, Glick. Long-Distance Nationalism. :570.

21. Humphrey, Michael. Lebanese Identities: Between Cities, Nations and Trans-Nations. Arab Studies Quarterly. 2004; 26:31-50.

22. Guarnizo, Luis Eduardo; Portes, Alejandro; Haller, William. Assimilation and Transnationalism: Determinants of Transnational Political Action among Contemporary Migrants. American Journal of Sociology. 2003; 108:1211-248.

23. Bauböck, Rainer. Towards a Political Theory of Migrants Transnationalism. International Migration Review. 2003; 37:700-23.Levitt, Peggy. Religion as a Path to Civic Engagement. Ethnic and Racial Studies. 2008; 31:766-91.Østergaard-Nielsen, Eva. The Politics of Migrants' Transnational Political Practices. International Migration Review. 2003; 37:760-86.

24. Leichtman, Mara A. The Legacy of Transnational Lives: Beyond the First Generation of Lebanese in Senegal. Ethnic and Racial Studies. 2005; 28:663-86.

25. Humphrey. Lebanese Identities. :42. 
26. Porta, Donnatella Della; Tarrow, Sidney. Transnational Protest and Global Activism. Lanham, Md: Rowman \& Littlefield; 2005. Transnational Processes and Social Activism: An Introduction; p. 2-3.

27. See Humphrey, Michael. Islam, Multiculturalism and Transnationalism: From the Lebanese Diaspora. LondonI. B. Tauris1998and Walbridge, Linda S. Without Forgetting the Imam: Lebanese Shi ism in an American Community. Detroit, MichWayne State University Press 1997

28. See Deeb, Lara. Exhibiting the 'Just-Lived Past': Hizbullah's Nationalist Narratives in Transnational Political Context. Comparative Studies in Society and History. 2008; 50:369-99.

29. Shaery-Eisenlohr. Shi'ite Lebanon.

30. Bowen, John R. Beyond Migration: Islam as a Transnational Public Space. Journal of Ethnic and Migration Studies. 2004; 30:879-94.Eickelman, Dale F.; Piscatori, James, editors. Muslim Travellers: Pilgrimage, Migration, and the Religious Imagination. Berkeley, Calif: University of California Press; 1990. Grillo, Ralph. Islam and Transnationalism. Journal of Ethnic and Migration Studies. 2004; 30:861-78.Levitt, Peggy. 'You Know, Abraham Was Really the First Immigrant': Religion and Transnational Migration. International Migration Review. 2003; 37:84773.Vertovec, Steven. [accessed 15 February 2005] Religion and Diaspora. ESRC Transnational Communities Programme Working Paper WPTC-01-01. 2000. http://

www.transcomm.ox.ac.ukAllievi, Stefano; Nielsen, Jørgen S., editors. Muslim Networks and Transnational Communities in and across Europe. Leiden: E. J. Brill; 2003. Diaspora, Transnationalism and Islam: Sites of Change and Modes of Research; p. 312-26.idemvan der Veer, Peter. [accessed 15 February 2005] Transnational Religion. ESRC Transnational Communities Programme Working Paper WPTC-01-18. 2001. www.transcomm.ox.ac.uk

31. Allievi, Stefano. Islam in the Public Space: Social Networks, Media and Neo-Communities. In: Allievi, Stefano; Nielsen, Jørgen S., editors. Muslim Networks and Transnational Communities in and across Europe. Leiden: E. J. Brill; 2003. p. 11

32. Louër. Transnational Shia Politics.

33. See Leichtman, Mara A. Revolution, Modernity and (Trans)National Shi i Islam: Rethinking Religious Conversion in Senegal. Journal of Religion in Africa. 2009; 39:319-51. [PubMed: 23833329]

34. Castells, Manuel. The Rise of the Network Society. Oxford: Basil Blackwell; 1997. p. 15

35. Roy, Olivier. Globalized Islam: The Search for a New Ummah. New York: Columbia University Press; 2004.

36. Mandaville. Transnational Muslim Politics.

37. Sayyid, S. Beyond Westphalia: Nations and Diasporas-The Case of the Muslim Umma. In: Hesse, Barnor, editor. Un/settled Multiculturalisms: Diasporas, Entanglements, Transruptions. London: Zed Books; 2000. p. 33-50.p. 36

38. Tölölyan's, Khachig. Rethinking Diaspora(s): Stateless Power in the Transnational Moment. Diaspora: A Journal of Transnational Studies. 1996; 5:3-36.considers only the Jewish, Armenian, and Greek cases to be paradigms of diasporas and regards other examples as representative of "all the multiplying dispersions that have been renamed as diasporas since 1968" (16) Cohen's, Robin. Global Diasporas: An Introduction. Seattle, WashUniversity of Washington1997does, however, consider the "great Lebanese emigration" to be an exemplary case of a trade diaspora. It is not the purpose of this article to engage with the growing and conflicting literature defining diaspora.

39. Migrant remittances from Africa have aided in the reconstruction of war-torn Lebanon, and there are even streets in southern Lebanon named "Senegal" and "Nigeria." For accounts of other West African Lebanese communities, see Bierwirth, Chris. The Lebanese Communities of Cote D'Ivoire. African Affairs. 1999; 98:79-99.Hourani, Albert; Shehadi, NadimThe Lebanese in the World: A Century of Emigration. LondonI. B. Tauris1992Peleikis, Anja. Lebanese in Motion: Gender and the Making of a Translocal Village. Bielefeld, GermanyTranscript2003van der Laan HL. The Lebanese Traders in Sierra Leone. The HagueMouton1975

40. Boumedouha, Said. PhD dissertation. University of Birmingham; 1987. The Lebanese in Senegal: A History of the Relationship Between an Immigrant Community and its French and African Rulers; p. 45-46.

41. See O'Brien, Rita Cruise. White Society in Black Africa: The French of Senegal. Evanston, IllNorthwestern University Press1972Harrison, Christopher. France and Islam in West Africa, 
1860-1960. CambridgeCambridge University Press1988Sene, Diégane. Un journal à l'assaut des 'Levantins. ' 'Les Echos Africains' et le 'Problème Libanais' en AOF (1947-1948). Revue Africaine de Communication. Centre d'Etudes des Sciences et Techniques de l'Information, Université Cheikh Anta Diop de DakarNov-Décembre;1997

42. See Leichtman, Mara A. A Tale of Two Shi 'isms: Lebanese Migrants and Senegalese Converts in Dakar. PhD dissertation. Brown University2006; chap 3

43. Some Lebanese were active party members; others gave financial help and lent party leaders their lorries to campaign in the Senegalese countryside.

44. Boumedouha, Said. The Lebanese in Senegal.

45. Thibault, Jean. Les Libanais en Afrique: Parasites ou Agents de Développement? Voix d'Afrique. 1976; 24:13-14.

46. See Gellar, Sheldon; Charlick, Robert B.; Jones, Yvonne. Animation Rurale and Rural Development: The Experience of Senegal. Ithaca, N.YCornell University, Center for International Studies, Rural Development Committee1980and Fatton, Robert, Jr. The Making of a Liberal Democracy: Senegal's Passive Revolution, 1975-1985. Boulder, ColoLynne Rienner1987

47. Boone, Catherine. Merchant Capital and the Roots of State Power in Senegal, 1930-1985. Cambridge: Cambridge University Press; 1992.

48. The Senegalese government was concerned that a few Lebanese with Senegalese citizenship had returned to Lebanon owing the state or local companies large sums of money. See Boumedouha. The Lebanese in Senegal.

49. See Leichtman. The Legacy of Transnational Lives.

50. See Leichtman, Mara A. From the Cross (and Crescent) to the Cedar and Back Again: Transnational Religion and Politics among Lebanese Christians in Senegal. Under journal review.

51. For more information on Musa al-Sadr see Ajami, Fouad. The Vanished Imam: Musa al Sadr and the Shia of Lebanon. Ithaca, N.YCornell University Press1986and Halawi, Majid. A Lebanon Defied: Musa al-Sadr and the Shia Community. Boulder, ColoWestview Press1992

52. Abdul, Al-Shaykh; Al-Zayn, Monem. L'Islam: Ma Doctrine et Ma Loi. 5. Dakar, Senegal: l'Institution Islamique Sociale; 2001. p. 3-4.

53. For a more detailed discussion on the work of Shaykh Al-Zayn, see Leichtman, Mara A. The Intricacies of Being Senegal's Lebanese Shi' ite Sheikh. Muslim Voices and Lives in the Contemporary World. Trix, Frances; Walbridge, John; Walbridge, LindaNew YorkPalgrave Macmillan2008:85-100.

54. See Chehabi. Distant Relations; Augustus Richard Norton, Amal and the Shi a: Struggle for the Soul of Lebanon. Austin, TexUniversity of Texas Press1987Hezbollah: A Short History. Princeton, N.JPrinceton University Press2007idemShaery-Eisenlohr. Shi'ite Lebanon. Shanahan, Rodger. The Shi'a of Lebanon: Clans, Parties and Clerics. LondonI. B. Tauris Academic Studies 2005

55. Hirschkind, Charles. The Ethical Soundscape: Cassette Sermons and Islamic Counterpublics. New York: Columbia University Press; 2006. Schulz, Dorothea E. Promises of (Im)mediate Salvation: Islam, Broadcast Media, and the Remaking of Religious Experience in Mali. American Ethnologist. 2006; 33:210-29.Soares, Benjamin F. Islam in Mali in the Neoliberal Era. African Affairs. 2006; 105:77-95.

56. Translations of the sermon are by Ebraima K. M. Saidy.

57. For a detailed account of al-Sadr's life and works see Mallat, Chibli. The Renewal of Islamic Law: Muhammad Baqer as-Sadr, Najaf and the Shi'i International. CambridgeCambridge University Press 1993

58. Deeb, Lara. Shi'i Lebanon. Princeton, N.J: Princeton University Press; 2006. An Enchanted Modern: Gender and Public Piety; p. 34Mahmood, Saba. Politics of Piety: The Islamic Revival and the Feminist Subject. Princeton, N.J: Princeton University Press; 2005.

59. See Deeb. An Enchanted Modern. :110-15., for a discussion of this literature.

60. Deeb. An Enchanted Modern, and Peleikis, Lebanese in Motion, have discussed different meanings of veiling for Lebanese women, where various styles carry associations with particular age groups and trends, protect against social pressure to conform to the increasing popularity of plastic surgery, and reflect political loyalties in Lebanon 
61. On Senegalese Shi'a see Leichtman, Mara A. The Authentication of a Discursive Islam: Shi'a Alternatives to Sufi Orders. New Perspectives on Islam in Senegal: Conversion, Migration, Wealth, Power and Femininity. Diouf, Mamadou; Leichtman, Mara A.New YorkPalgrave Macmillan2009:111-38.and Revolution, Modernity and (Trans)National Shi ism. idem.

62. For a discussion of "the Karbala paradigm" and its use during the Iranian Revolution, see Fischer, Michael MJ. Iran: From Religious Dispute to Revolution. Cambridge, MassHarvard University Press 1980and Aghaie, Kamran S. The Martyrs of Karbala: Shi i Symbols and Rituals in Modern Iran. Seattle, WashUniversity of Washington Press2004

63. Khums is the Shi'i tax of one-fifth of all wealth.

64. Cohen, Abner. Custom and Politics in Urban Africa: A Study of Hausa Migrants in Yoruba Towns. Berkeley, Calif: University of California Press; 1969. p. 141

65. See Leichtman. From the Cross (and Crescent) to the Cedar.

66. For an excellent discussion of the relationship of solidarity between Hizbullah and the Palestinians, see Khalili, Laleh. 'Standing with My Brother': Hizbullah, Palestinians, and the Limits of Solidarity. Comparative Studies in Society and History. 2007; 49:276-303.

67. It is also significant that Berri was born in Sierra Leone. Not only do Lebanese in Senegal have ties with other Lebanese communities throughout West Africa, in particular in Ivory Coast, but also Lebanese from Africa hold important political positions in Lebanon.

68. Mermier, Franck; Picard, Elizabeth. Liban, une guerre de 33 jours. ParisEditions La Découverte2007See also Shaery-Eisenlohr. Shi'ite Lebanon. Deeb. Exhibiting the 'Just-Lived Past'. Mervin, SabrinaLe Hezbollah état des lieux. ParisSindbad2008

69. Les Libanais ont manifesté jeudi à Dakar contres les raids israéliens. Panapress. accessed 15 July 2008http://www.grioo.com/pinfo7373.htmlFor other descriptions of the protests in Senegalese newspapers, see La chaîine de solidarité libano-sénégalaise. Le Quotidien. Jul 21.2006 :4.Massaly, Yakhya. Les libanais du Sénégal manifestent contre les attaques. Walfadjri. Jul 21.2006 :2.Mané, Daouda. Marche de solidarité avec le peuple libanais. Le Soleil. Jul 21.2006 :3.

70. La chaîine de solidarité libano-sénégalaise. Le Quotidien. Jul 21.2006 :4.

71. Les Libanais du Sénégal veulent la fermeture de l'ambassade d'Israël. Le Quotidien. Jul 22$23.2006: 4$.

72. La communauté libanaise ne doit pas dicter la politique étrangère du Sénégal. Le Quotidien. Jul $25.2006: 8$.

73. Qana was first shelled by Israeli artillery on 18 April 1996, resulting in a large number of civilian deaths and injuries. The second airstrike by Israel was on 30 July 2006, when an apartment building was hit, killing many civilians, especially children. On the Qana memorial see Volk, Lucia. Re-Remembering the Dead: A Genealogy of a Martyrs Memorial in South Lebanon. Arab Studies Journal. 2007; 15:44-69.

74. For a summary of Shaykh al-Zayn's politics during the war and his linking the 2006 Lebanon War to the battle of Karbala, see Gaye, Amadou. Cheikh Abdel Monem El Zayn 'Cette guerre fera tomber les régimes arabes non solidaires au Hezbollah,'. Le Soleil. Aug 18.2006 :19.

75. I was told that approximately 3,000 Lebanese were in attendance in addition to one Senegalese representative of the government.

76. The Lebanese Maronite Church was founded in Dakar by Father Augustin Sarkis in 1952. See Leichtman. From the Cross (and Crescent) to the Cedar.

77. These victims included relatives of those in Senegal.

78. See Norton, Hezbollah; Shaery-Eisenlohr. Shi ite Lebanon.

79. 'Ali, Husayn's father, was the first Shi'i Imam.

80. Al-Manar is also watched by non-Shi i Arabs who appreciate its emphasis on the Palestinian struggle.

81. Although Shaykh al-Zayn follows Ayatollah al-Sistani, many Lebanese in Senegal are not aware of or are confused by the Shi'i marja iyya. Some consider Shaykh al-Zayn to be their marja', while others follow al-Sistani or Fadlallah or prefer the rulings of Ayatollah al-Khu'i even though he is no longer alive.

82. Tsing, Anna L. In the Realm of the Diamond Queen: Marginality in an Out-of-the-Way Place. Princeton, N.J: Princeton University Press; 1993. 
83. This is currently a topic of debate in Lebanon, and Notre Dame University's Lebanese Emigration Research Center is surveying the Lebanese diaspora on the question of absentee voting.

84. Levitt, Peggy; Schiller, Nina Glick. Conceptualizing Simultaneity: A Transnational Social Field Perspective on Society. International Migration Review. 2004; 38:1002-1039.

85. Mandaville. Transnational Muslim Politics. :109.

86. Roy. Globalized Islam. He suggests that the tullāb (students) who have turned to the Internet dominate these debates instead. 